\begin{tabular}{|c|c|c|}
\hline & Int.J.Curr.Microbiol.App.Sci (2021) 10(09): 391-401 & \\
\hline & $\begin{array}{l}\text { International Journal of Current Microbiology and Applied Sciences } \\
\text { ISSN: 2319-7706 Volume } 10 \text { Number } 09 \text { (2021) } \\
\text { Journal homepage: } \underline{\text { http://www.ijcmas.com }}\end{array}$ & $\$$ \\
\hline $\begin{array}{l}\text { EXCELLENT } \\
\text { PUBLISHERS }\end{array}$ & & www. ijemas.com \\
\hline
\end{tabular}

\title{
Food and Feeding Habits of the Bivalve Cardium costatum (Linné, 1758) in the Exclusive Economic Zone of Côte d'Ivoire
}

\author{
Kouato Fulgence $^{1 *}$, Kouakou Fokouo Kessia Irène ${ }^{1}$, Agnissan Aka Jean-Paul ${ }^{1}$ \\ and Otchoumou Atcho'
}

${ }^{1}$ Department of Animal Biology, Formation Unit and Research of Biological Sciences, University Peleforo Gon Coulibaly, BP 1328 Korhogo, Côte d'Ivoire

${ }^{2}$ Laboratory of Animal Biology and Cytology, Formation Unit and Research of Natural Sciences, University Nangui Abrogoua, 02 BP 801 Abidjan, Côte d'Ivoire

*Corresponding author

\section{A B S T R A C T}

Keywords

Stomach contents, diet, phytoplankton, marine season, Ivory Coast

Article Info

Accepted:

15 August 2021

Available Online:

10 September 2021
The diet of 400 specimens of Cardium costatum from the exclusive economic zone of Côte d'Ivoire was studied for two years depending on the hydrological seasons and the size of the individuals. Stomach contents were analyzed using frequency of occurrence, numerical frequency, and specific abundance methods. The results obtained show that this bivalve is a planktophagus and also feeds on inert organic matter (detritus) and bacteria. Phytoplankton forms the major constituent of its diet regardless of season and size. However, most immature young people have a specialist feeding strategy for Navicula and mature ones prefer Amphora.

\section{Introduction}

Molluscs bivalves occupy all marine ecological niches, from the coast to great depths. They intervene at lower trophic levels in marine ecosystems by transferring energy through links in the food chain (Derbali, 2011). They play an important role in the ecosystem by stabilizing the seabed by the formation of clumped shell beds that protect loose sediments against erosion (Reneerkens et al., 2005). They are used for the production of pearls, as a source of calcium in animal feed (Bouyé et al., 2013), as a source of protein in human food (China et al., 2003) and are a collector's item.

In Côte d'Ivoire, bivalve fishing is poorly known, and even absent from the reports of the Department of Fisheries and Aquaculture. However, bivalves constitute a source of animal protein and a significant economic potential for coastal populations like the cupped oyster Crassostrea gasar. The absence 
of management measures could therefore inevitably lead to an often irreversible degradation of the ecosystems involved in the event of intense exploitation of the natural stock. This lack of interest in these species, both in the scientific and economic sectors, does not seem justifiable given the importance of these species. In addition, field surveys have shown that trawlers operating in the Ivorian Exclusive Economic Zone (EEZ) fish and land bivalve molluscs. According to them, the species Cardium costatum constitutes the most frequent species, and abundant in fisheries. Knowledge of the biology, in particular the diet of Cardium costatum, seems crucial to us for sustainable management, the development of breeding and the promotion of this resource to consumers.

This work aims to study the diet of this marine bivalve in order to understand the feeding strategy adopted by the species in its environment.

\section{Materials and Methods}

The diet study involved a total of 400 stomachs which were collected during the period from November 2012 to October 2014. Bivalves are transported under rice, from the fishing port of Abidjan (commercial fishing) to the laboratory in coolers. In the laboratory, they are dissected and each visceral mass is removed, washed and weighed then stored in a $50 \mathrm{ml}$ capacity pill container containing 5\% formalin. The visceral mass is taken out of the pillbox and weighed after having been rinsed with copious amounts of water, then wrung out on blotting paper. After incision and recovery of the stomach contents in boxes of $50 \mathrm{ml}$ capacity, the wall of the stomach is rinsed with $10 \mathrm{ml}$ of distilled water using a squeeze bottle to collect the other prey which has remained stuck to the walls. The volume of prey is reduced to $30 \mathrm{ml}$ by adding water distilled; to this volume we add $10 \mathrm{ml}$ of $5 \%$ formalin. The samples thus obtained are labeled.

Mounts between slide and cover slip of one milliliter of the solution containing the prey are carried out for the identification of phytoplankton and Zooplankton. The identification of phytoplankton is made using the keys of Compère (1975); Rumeau and Coste (1988); Paulmier (1992); Komarek and Anagnostidis (1998). Identification of the species often requires other methods other than microscopic observation. Therefore, we will limit our identification to gender. In addition, the phytoplankton count is carried out under an optical microscope using a Bükercell. Zooplankton will be identified using the keys of Pourriot (1980), Pourriot et al., (1982); Forcellini et al., (2011). The count is also done under a microscope using the Dolfusscell. Then, by extrapolation, the number of individuals (Phytoplankton and Zooplankton) in the $40 \mathrm{ml}$ sample was estimated.

The coefficients and indices used are:

The corrected percentage of occurrence to determine the food preferences of a given species:

$\mathrm{Fc}=(\mathrm{Fi} / \Sigma \mathrm{Fi}) \times 100$, where $\mathrm{Fi}=$ frequency of occurrence with $\mathrm{Fi}=\mathrm{Ne} / \mathrm{Nt}$

With $\mathrm{Ne}$, the number of stomachs containing a prey category $\mathrm{i}$ and $\mathrm{Nt}$, the total number of stomachs containing at least one prey (Paugy et al., 1999; Gray et al., 1997).

The numerical percentage (N) (Lauzanne, 1975; Hyslop, 1980) which represents the proportion of a prey category $i$ in the whole of the stomach contents:

$\mathrm{N}=(\mathrm{Ni} / \mathrm{Nt}) \times 100$ where $\mathrm{Ni}=$ total number of a prey category $\mathrm{i}$ and $\mathrm{Nt}=$ total number of 
all prey. The specific abundance index (Si) which is calculated on the basis of knowledge of the number, volume or weight of prey and expressing the proportion of each prey category $\mathrm{i}$, only in the stomachs where it is encountered (Amundsen et al., 1996) is determined according to the following relation:

$\mathrm{Si}=\mathrm{ai} /$ ati with ai, total abundance of prey $\mathrm{i}$ and ati, total abundance of all prey only in all stomachs containing prey $i$.

The empty stomachs were counted and the coefficient of emptiness $(\mathrm{Cv})$ which expresses the percentage of empty stomachs was calculated by the formula:

$\mathrm{Cv}=(\mathrm{Nv} / \mathrm{Nt}) \times 100$

Microscopic observation of the male and female gonads made it possible to group the bivalves into two size classes according to the size at first sexual maturity (L50).

The minimum size at first sexual maturity (L50) was considered to be a limit. Thus all the individual shaving a standard length less than this reference size constitute the immature class (juveniles) and those of greater size, the mature class (adults).

Comparisons of diet between the two life stages and between seasons were made using the Schoener index (Schoener, 1970). It was used to assess the degree of similarity between stages of maturity and seasons.

$\alpha=1-0,5\left(\sum_{i=1}^{n}\left|p_{x i}-p_{y i}\right|\right)$

Pxi $=$ proportion of a prey $\mathrm{i}$ consumed by a maturity stage or individuals of a season (x),

Pyi $=$ proportion of a prey $\mathrm{i}$ consumed by a maturity stage individuals of a season $(y)$.
Diets are considered significantly similar when the $\alpha$ value is greater than 0.6 (Wallace, 1981).

\section{Food Ethology}

The graphic method of Costello (1990), modified by Amundsen et al., (1996) was chosen to describe variations in diet. This method relates the diet of a given species to its feeding strategy (figure 1). It makes it possible to analyze the importance of preys, their contribution to the extent of the trophic niche and their feeding strategy. The diagram by Amundsen et al., (1996) represents the specific abundance $(\mathrm{Si})$ as a function of the occurrence $(\mathrm{Fc})$. The diagonal starting from the bottom left to the top right characterizes the importance of the prey which can be rare or dominant. The diagonal from the top left to the bottom right indicates the width of the niche.

\section{Results and Discussion}

\section{General diet profile}

A total of 400 stomachs were examined in Cardium costatum. No stomach was empty, giving a percentage of emptiness of $0 \%$. The stomach contents consist of planktonicprey (Phytoplankton and Zooplankton), detritus and indeterminate elements (Table 1). The prey (Phytoplankton and Zooplankton) are divided into six (6) groups. Phytoplankton is made up of Dinoflagellates (Amphisolenia sp, Dinophysis sp), Diatoms (centric and Pennate) and Cyanobacteria (Oscillatoria sp, Synechococcus sp). As for Zooplankton, it includes Copepods, Foraminifera and Rotifers.

Numerically, the most abundant foods are Diatoms (70.8\%) with a dominance of Pennates $(61.1 \%)$. They are followed by Dinoflagellates $(13.7 \%)$. The classification of foods from the corrected occurrence 
percentages indicates that Diatoms (54.9\%), detritus $(22.2 \%)$ are important, then come Dinoflagellates (14.3\%) and Zooplankton (5, $2 \%)$. Among the Diatoms, the Pennates $(34.8 \%)$ are the most consumed preys. These results are consistent with the conclusions of Dabouineau and Ponsero (2004); Sarà (2007), Pernet et al., (2012) who also worked on other species of Bivalves. However, phytoplankton undoubtedly forms the major constituent of this diet. This resultis in agreement withthose of Helmet al., (2006). Among the phytoplankton, Diatomsturn out to be the most consumed preys with a preference for Pennates (Navicula sp and Amphora sp). In addition, Sarà (2007), in his studies on the nutrient sources of the hull, has shown that microalgae (especially Diatoms) and phanerogams constitute the main food bolus of the species Cerastoderma glaucum. The preference for Pennate Diatoms could be explained by the fact that the Bivalves being benthic organisms, it would be easier to consume the Pennates which are also benthic.

According to Hennebelle (1975), with the exception of the Pectinidae which are likely to move, most of the Lamellibranchs (clams, cockles) are benthic organisms and live buried in the sediment. The benthic biotope of $C$. costatum which is part of the Cardiidae (cockles) family could influence their food preference.

\section{Feeding strategy of Cardium costatum}

The Costello diagram (Figure 2) shows that $C$. costatum has a specialist diet, with variability in resource use by individuals.

The $C$. costatum population is thus subdivided into sub-populations each specialized in the use of a well-defined resource. One subpopulation has a preference for filtering Navicula sp and another subpopulation has a preference for the genus Amphora sp.

\section{Diet of Cardium costatum according to the marine seasons}

Based on the numerical percentage, Diatoms with $57.4 \%$ are the most abundant preys during the warm seasons (Large and Small). Among these Diatoms, the Pennates are the most abundant preys $(46.8 \%)$. They are followed by Dinoflagellates $(14.4 \%)$.

During the cold seasons (large and small), Diatoms with $75.8 \%$ numerical percentage are the most important preys. They are dominated by the Pennates (64.6\%). Dinoflagellates (11.7\%) come second (Table 2).

Based on occurrence, Diatoms are the most important preys in both seasons with $43.5 \%$ for hot seasons and $57.2 \%$ for cold seasons. Then comes the rubbish with $31.3 \%$ for the hot seasons and $17.4 \%$ for the cold seasons.

The Costello diagram during the hot season (Figure 3A) shows that the population of Cardium costatum is specialist. It is nevertheless subdivided into sub-populations, each preferring a well-defined resource. One subpopulation prefers the filtering of Navicula sp and another subpopulation prefers the genus Amphora sp.

According to the Costello diagram there is variability in the use of resources by individuals during the cold season (Figure 3B). The population of Cardium costatum is subdivided into two subpopulations. One group of individuals has specialized in consuming Navicula sp and another tends to prefer Amphora sp. There was no remarkable specific grouping around Centric Diatoms, Cyanobacteria, Dinoflagellates, Foraminifera, Copepods and Rotifers. These groups are rarely consumed. C. costatum prefers phytoplankton whatever the season. This could be due to their availability both during the cold and hot seasons in the Ivorian 
exclusive economic zone. Indeed, the phytoplankton population is linked to variations in the marine seasons. Dinoflagellates are very abundant during the great hot season (Reyssac, 1993). They express a remarkable tolerance to temperature. An increase in the consumption of Dinoflagellates is observed during the hot season. According to Binet (1983) and Herblandand Le Loeuff (1993), the high concentration of chlorophyll a which could be observed during warm sea seasons indicates that land inputs contribute to the enrichment of the Ivorian coastal zone. The enriching inputs come from runoff which leaches cleared land surrounding the coastal lagoons. Consequently, terrigenous inputs would lead to a high concentration of phytoplankton during the hot seasons. During the cold seasons, the Dinoflagellates gradually disappear to make room for the Diatoms. According to the work of Reyssac (1993), Diatoms are species well adapted to cold waters. These phenomena (terrigenous inputs and upwellings phenomena) allow phytoplankton availability both during hot and cold seasons. Analysis of stomach contents shows a zero emptiness coefficient (0). This state indicates greater accessibility to food during all times of the year. Terrigenous inputs would lead to a high concentration of phytoplankton during hot seasons. During the cold seasons, the Dinoflagellates gradually disappear to make room for the Diatoms. According to the work of Reyssac (1993), Diatoms are species well adapted to cold waters. These phenomena (terrigenous inputs and upwellings phenomena) allow phytoplankton availability both during hot and cold seasons.

\section{Diet of Cardium costatum based on sexual maturity}

Based on the numerical percentage (Table 3), Diatoms with $77.4 \%$ are the most abundant prey in immature individuals $(<57 \mathrm{~mm})$.
Among these Diatoms, the Pennates are the most abundant preys (64.6\%). They are followed by Centric Diatoms (12.8\%), Zooplankton (9.6) and Dinoflagellates (7.3\%).

In mature individuals (> $66 \mathrm{~mm}$ ), Diatoms with $64.7 \%$ numerical percentage constitute the most important preys. They are dominated by Pennates (51.2\%), followed by Dinoflagellates $(14.3 \%)$, Centric Diatoms (13.5\%) and Zooplankton (12.8\%).

Based on the occurrence (Table 3), Diatoms constitute the most important prey in both size classes with $43.4 \%$ for immature individuals of Cardium costatum and $50.5 \%$ for mature individuals of $C$. costatum. Then comes the detritus with $21.4 \%$ for the small sizes of $C$. costatum and $28.3 \%$ for the large sizes of $C$. costatum.

Regarding the feeding strategy, the analysis of the Costello diagram (Figure 4C) of immature individuals in $C$. costatum shows that the species has a specialist diet, with a population specialized in the consumption of Navicula sp. Analysis of the Costello diagram (Figure 4D) of mature individuals in $C$. costatum shows that the mature population of $C$. costatum is specialized in the consumption of Amphora sp.

The size-based diet shows that regardless of size, C. costatum retains its preferences for phytoplankton. However, most immature young have a specialist feeding strategy for Navicula sp and mature ones prefer Amphora sp. In addition, young individuals do not have copepods or for aminifera in their diet. This absence would be due either to a selection or to a size of prey which does not allow them to consume them. According to Morton (1960), Bivalves can exercise a certain selection of their food. Doumenc (1993) showed that the marine water entering through the inhalant siphon is filtered by the gills. 
Table.1 Composition of the general diet of Cardium costatum

\begin{tabular}{|c|c|c|c|}
\hline Prey & $\mathbf{N}(\boldsymbol{\%})$ & Fc $(\boldsymbol{\%})$ & $\mathbf{S}(\boldsymbol{\%})$ \\
\hline Phytoplankton & $\mathbf{8 9 . 3}$ & $\mathbf{7 0}$ & $\mathbf{8 5 . 1}$ \\
\hline Dinoflagellates & $\mathbf{1 3 . 7}$ & $\mathbf{1 4 . 3}$ & $\mathbf{1 9 . 7}$ \\
\hline Amphisolenia sp & 7.5 & 7.6 & 20.8 \\
Dinophysis sp & 6.2 & 6.7 & 8.4 \\
\hline DIATOMS & $\mathbf{7 0 . 8}$ & $\mathbf{5 4 . 9}$ & $\mathbf{6 0 . 8}$ \\
\hline Pennate Diatoms & $\mathbf{6 1 . 1}$ & $\mathbf{3 4 . 8}$ & $\mathbf{6 5 . 6}$ \\
\hline Amphora sp & 21.3 & 14.1 & 47.1 \\
\hline Navicula sp & 36.7 & 19.4 & 55.9 \\
Nitzschia sp & 3.1 & 1.3 & 10.9 \\
\hline Centric Diatoms & $\mathbf{9 . 7}$ & $\mathbf{1 9 . 1}$ & $\mathbf{2 1 . 5}$ \\
\hline Actinoptychu ssp & 0.2 & 1.2 & 9.7 \\
\hline Chaetoceros sp & 3.6 & 6.8 & 11.1 \\
\hline Conscinodiscus sp & 5.7 & 0.4 & 17.1 \\
Rhizosolenia sp & 0.2 & 10.7 & 5.7 \\
\hline Cyanobacteria & $\mathbf{3 . 8}$ & $\mathbf{1 . 8}$ & $\mathbf{1 0 . 7}$ \\
\hline Oxillatoria sp & 3.1 & 1.3 & 6.7 \\
\hline Synechococcus sp & 0.7 & 0.5 & 8.7 \\
\hline Zooplankton & $\mathbf{5 . 2}$ & $\mathbf{5 . 5}$ & $\mathbf{1 8 . 7}$ \\
\hline Copepods & 0.1 & 1.8 & 7.4 \\
\hline Foraminifera & 1.4 & 1.1 & 9.7 \\
\hline Rotifers & 3.7 & 2.6 & 5.1 \\
\hline Detritus & - & $\mathbf{2 2 . 2}$ & - \\
\hline Indetermined & $\mathbf{5 , 5}$ & $\mathbf{2 , 3}$ & $\mathbf{1 7}$ \\
\hline
\end{tabular}

N:numerical percentage, Fc: corrected percentage of occurrence, S: specific abundance.

Fig.1 Interpretation of the Costello graph (Amundsen et al., 1996)

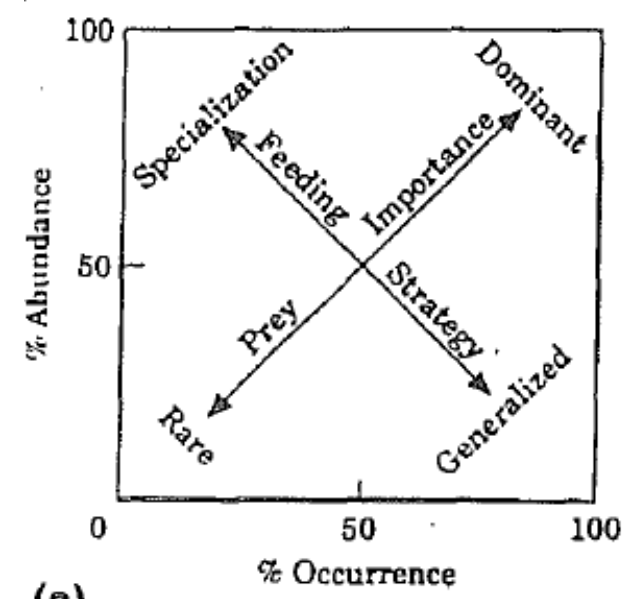

(a)

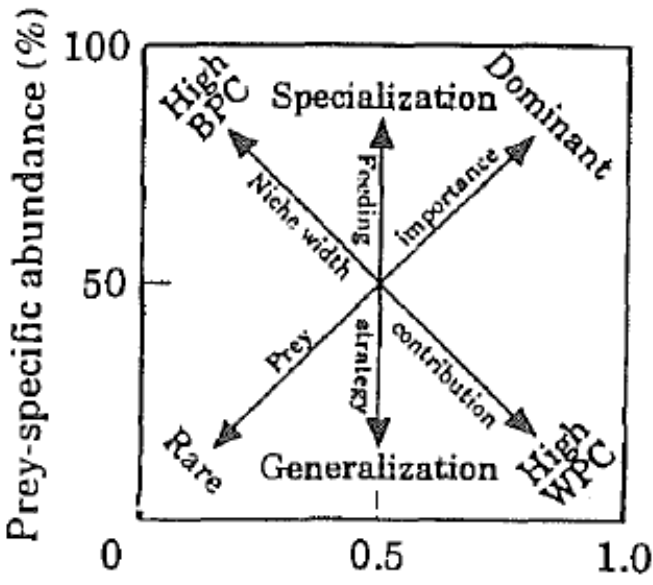

(b) Frequency of occurrence

Costello (1990) and (b) Amundsen et al. (1996) (BPC= between-phenotype component, WPC= within-phenotype component). 
Table.2 Composition of the diet of Cardium costatum according to the seasons

\begin{tabular}{|c|c|c|c|c|c|c|}
\hline \multirow[t]{2}{*}{ Prey } & \multicolumn{3}{|c|}{ Hot saisons } & \multicolumn{3}{|c|}{ Cold saisons } \\
\hline & $\mathrm{N}(\%)$ & $\mathrm{Fc}(\%)$ & $\mathrm{S}(\%)$ & $\mathrm{N}(\%)$ & Fc $(\%)$ & $\mathrm{S}(\%)$ \\
\hline Phytoplankton & 84.1 & 58.7 & 84.2 & 89.7 & 68.8 & 89.3 \\
\hline Dinoflagellates & 14.4 & 10.1 & 24.7 & 11.7 & 9.5 & 21.5 \\
\hline Amphisolenia & 9.5 & 6.6 & 11.8 & 7 & 8.5 & 15.5 \\
\hline Dinophysis & 4.9 & 3.5 & 9.4 & 4.7 & 0.9 & 11.6 \\
\hline DIATOMS & 57.4 & 43.5 & 25.8 & 75.8 & 57.2 & 42.5 \\
\hline Pennate Diatoms & 46.8 & 33.4 & 36.9 & 64.6 & 40.3 & 68.9 \\
\hline Amphora sp & 11.7 & 10.7 & 37.1 & 20.3 & 8.1 & 29.1 \\
\hline Navicula sp & 33.3 & 21.1 & 41.1 & 39.6 & 29.1 & 57.1 \\
\hline Nitzschia sp & 1.8 & 1.6 & 12.9 & 4.7 & 3.1 & 7.8 \\
\hline Centric Diatoms & 10.4 & 10.1 & 12.5 & 11.2 & 16.9 & 14.5 \\
\hline Actinoptychus sp & 2.4 & 1.2 & 5.7 & 2.1 & 0.6 & 11.7 \\
\hline Chaetoceros sp & 3.5 & 4.1 & 18.2 & 3.8 & 4.8 & 8.1 \\
\hline Conscinodiscus sp & 3.1 & 4 & 20.2 & 3.8 & 10.1 & 19.7 \\
\hline Rhizosolenia sp & 1.4 & 0.8 & 2.7 & 1.5 & 1.4 & 7.4 \\
\hline Cyanobacteria & 5.3 & 5.1 & 10.6 & 2.2 & 2.1 & 8.7 \\
\hline Oxillatoria sp & 4.8 & 3.6 & 11.7 & 1.9 & 1.8 & 8.1 \\
\hline Synechococcu ssp & 0.5 & 1.5 & 8.5 & 0.3 & 0.3 & 7.1 \\
\hline Zooplankton & 8.8 & 6.8 & 10.2 & 5.2 & 8.1 & 18.7 \\
\hline Copepods & 2.1 & 0.9 & 4.6 & 1.1 & 0.7 & 5.7 \\
\hline Foraminifera & 2.4 & 1.5 & 6.7 & 1.4 & 1.1 & 6.7 \\
\hline Rotifers & 4.3 & 4.4 & 14.2 & 2.7 & 6.3 & 15.8 \\
\hline Detritus & - & 31.3 & - & - & 17.4 & - \\
\hline Indetermined & 7.1 & 3.2 & 8.4 & 5.1 & 5.7 & 12.8 \\
\hline
\end{tabular}

Fc:corrected percentage of occurrence, N: numerical percentage, S: specific abundance.

Fig.2 Costello diagram describing the feeding strategy of Cardium costatum

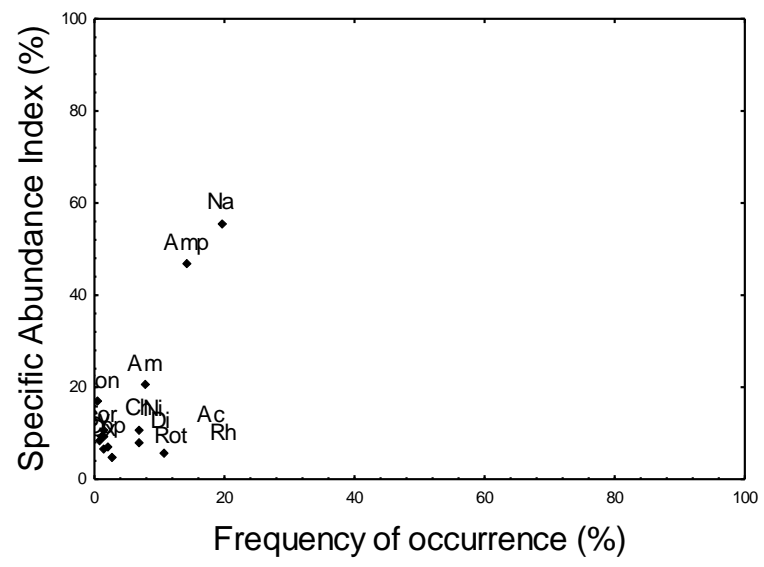

Am : Amphisolenia sp; Di : Dinophysis sp; Amp : Amphora sp Na : Navicula sp; Ni : Nitzschiasp; Ac : Actinoptychus sp ; Ch: Chaetocerossp; Con : Conscinodiscus sp; Rh: Rhizosolenia sp; Ox : Oxillatoria sp; Co : Copepods ; Sy : Synechococcus sp.Fo : Foraminifera; Ro : Rotifers. 
Table.3 Composition of the diet of Cardium costatum according to the size

\begin{tabular}{|c|c|c|c|c|c|c|}
\hline \multirow[t]{2}{*}{ Prey } & \multicolumn{3}{|c|}{ Size $<57$} & \multicolumn{3}{|c|}{ Size $\geq 66$} \\
\hline & $\mathrm{N}(\%)$ & Fc $(\%)$ & $\mathbf{S}(\%)$ & $\mathrm{N}(\%)$ & Fc $(\%)$ & $\mathbf{S}(\%)$ \\
\hline Phytoplankton & 85.4 & 61.1 & 85.1 & 82.3 & 58.8 & 89.7 \\
\hline Dinoflagellates & 7.3 & 11.7 & 19.7 & 14.3 & 6.5 & 21.7 \\
\hline Amphisolenia sp & 4.6 & 13.4 & 10.8 & 12.6 & 3.8 & 21.8 \\
\hline Dinophysis sp & 2.7 & 1.1 & 8.4 & 1.7 & 2.7 & 11.4 \\
\hline Diatoms & 77.4 & 43.4 & 70.1 & 64.7 & 50.5 & 69.8 \\
\hline Pennate Diatoms & 64.6 & 32.1 & 52 & 51.2 & 37.8 & 71.9 \\
\hline Amphora sp & 22.8 & 5.2 & 25.1 & 7.3 & 14.4 & 55.1 \\
\hline Navicula sp & 41.4 & 25.7 & 63.1 & 42.4 & 21.1 & 48.1 \\
\hline Nitzschia sp & 0.4 & 1.2 & 6.9 & 1.5 & 3.5 & 9.9 \\
\hline CentricDiatoms & 12.8 & 11.3 & 21.5 & 13.5 & 12.7 & 11.5 \\
\hline Actinoptychus sp & 1.6 & 2.2 & 9.7 & 6.6 & 2.1 & 19.7 \\
\hline Chaetoceros sp & 0.1 & 1.8 & 14.1 & 3.9 & 0.9 & 5.1 \\
\hline Conscinodiscus sp & 7.9 & 5.9 & 20.1 & 2.7 & 9.2 & 5.4 \\
\hline Rhizosolenia sp & 2.3 & 1.4 & 5.7 & 0.3 & 0.5 & 0.7 \\
\hline Cyanobacteria & 0.7 & 5.9 & 9.7 & 3.3 & 1.8 & 11.7 \\
\hline Oxillatoria sp & 0.7 & 5.9 & 9.7 & 2.7 & 0.4 & 8.4 \\
\hline Synechococcus sp & - & - & - & 0.6 & 1.4 & 0.8 \\
\hline Zooplankton & 9.6 & 10.3 & 8.8 & 12.8 & 8.1 & 18.7 \\
\hline Copepods & - & - & - & 2.1 & 0.7 & 5.7 \\
\hline Foraminifera & - & . & - & 2.4 & 0.1 & 6.7 \\
\hline Rotifers & 9.6 & 10.3 & 8.8 & 8.3 & 7.3 & 15.8 \\
\hline Detritus & - & 21.4 & - & - & 28.3 & - \\
\hline Indetermined & 5 & 7.3 & 12.8 & 4.9 & 4.8 & 10.8 \\
\hline
\end{tabular}

Fc:corrected percentage of occurrence, N: numerical percentage, S: specificabundance.

Fig.3 Costello diagramdescribing the feeding strategy of Cardium costatum during hot season (A) and cold season (B):Am = Amphisoleniasp; $\mathrm{Di}=$ Dinophysis $\mathrm{sp} ; \mathrm{Amp}=$ Amphora $\mathrm{sp} \mathrm{Na}=$ Navicula sp; $\mathrm{Ni}=$ Nitzschiasp $; \mathrm{Ac}=$ Actinoptychus $\mathrm{sp} ; \mathrm{Ch}=$ Chaetocerossp $; \mathrm{Con}=$ Conscinodiscussp $; \mathrm{Rh}=$ Rhizosolenia $\mathrm{sp} ; \mathrm{Ox}=$ Oxillatoria $\mathrm{sp} ; \mathrm{Co}=$ Copepods $; \mathrm{Sy}=$ Synechococcussp, Fo = Foraminifera; Ro $=$ Rotifers.
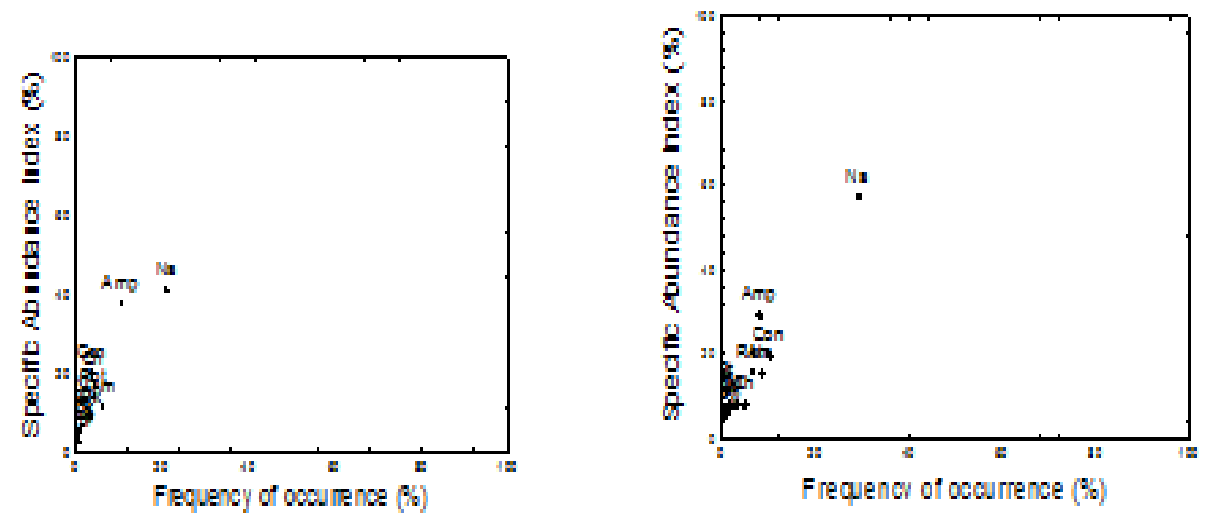
Fig.4 Costello diagram describing the feeding strategy of Cardium costatum according to the stage of sexual maturity $(\mathrm{C}=$ immature individuals $($ size $\leq 57 \%)$ and $\mathrm{D}=$ mature individuals

(size $\geq 66$ ).
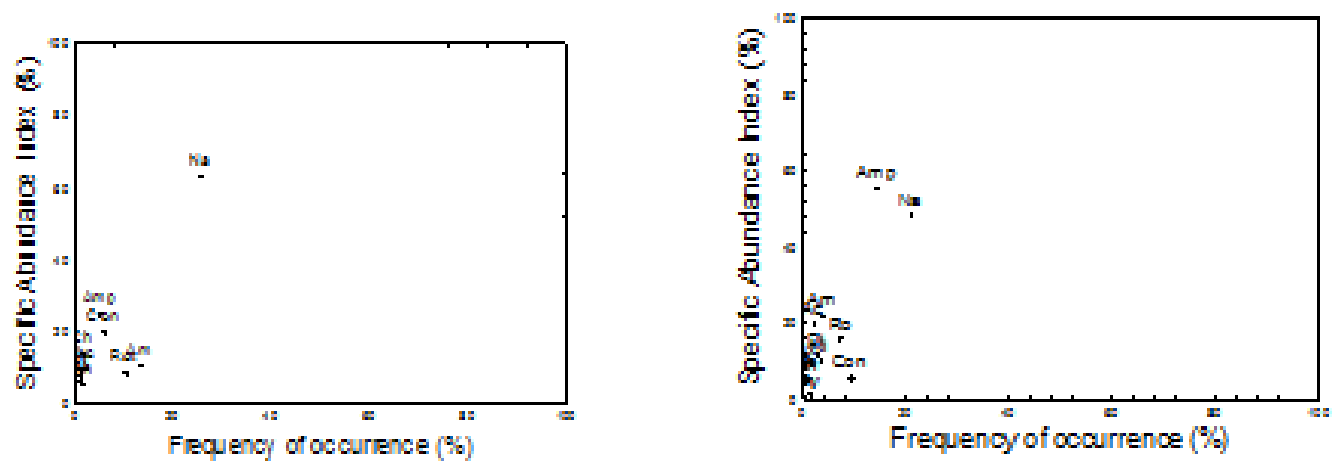

$\mathrm{Am}=$ Amphisolenia $\mathrm{sp} ; \mathrm{Di}=$ Dinophysis $\mathrm{sp} ;$ Amp = Amphora $\mathrm{sp} \mathrm{Na}=$ Navicula $\mathrm{sp} ; \mathrm{Ni}=$ Nitzschia $\mathrm{sp}$;

$\mathrm{Ac}=$ Actinoptychus $\mathrm{sp} ; \mathrm{Ch}=$ Chaetoceros $\mathrm{sp} ; \mathrm{Con}=$ Conscinodiscussp $; \mathrm{Rh}=$ Rhizosolenia $\mathrm{sp}$;

$\mathrm{Ox}=$ Oxillatoria $\mathrm{sp} ; \mathrm{Fo}$ : Foraminifera; $\mathrm{Co}=$ Copepods, $\mathrm{Ro}=$ Rotifers.

The particles are thus transported to the mouth by the vibratile ciliates and sorted by labial palps before being ingested. In addition, the lack of some prey in juveniles could be due to the size of the prey of $C$. costatum. According to Lubet (1973), the size of the particlesis the first selection criterion in mussels. Indeed, the particles which cannot penetrate into the mouth because of their sizes, are rejected in the form of pseudofeces. The high consumption of Navicula sp observed during the two years of study could be due to the specialist diet of young individuals of the genus Navicula sp. Indeed, according to His and Cantin (1995), there is a correlation between the size of individuals and filtration in mussels. Young individuals, small sizes have a higher filtration rate than large adult individuals. Young individuals of Cardium costatum would filter particles faster and therefore ingest large numbers of prey (His and Cantin 1995).

\section{Dietary overlap of Cardium costatum according to sea seasons and according to size}

$C$. costatum has a high dietary overlap index $(\alpha=1)$ and greater than 0.6 depending on the hot and cold marine seasons. This clue shows that $C$. costatum exhibits a similar diet during cold and hot seasons. Regarding the dietary overlap of $C$. costatum as a function of maturity size, the overlap index $(\alpha=0.89)$ of the two size classes exceeds the cut-off value (0.6). Immature and mature $C$. costatum also exhibit a similar diet. This could mean that there is food competition between individuals of the two size classes.

This food similarity according to the marine seasons and according to the size of maturity could be explained by the availability of most of the prey in the exclusive economic zone during the different marine seasons. This result is in agreement with those of Herbland and Le Loeuff (1993) and Reyssac (1993). Indeed, these authors have shown a high concentration of phytoplankton during all marine seasons due to upwelling phenomena during cold seasons and to terrigenous inputs during hot seasons.

\section{References}

Amundsen P. A., Gabler H. M. \& Staldvik F. J., 1996. A new approach to graphical analysis of feeding strategy from stomach contents data-Modification of 
the Costello (1990) method. Journal of Fish Biology, 48 : 607-614.

Bouyé T. R., Sika A., Memel J. D., Karamoko M. \& Otchoumou A., 2013. Effets de la teneur en poudre de coquilles de Bivalves (Corbulatrigona) du substrat sur les paramètres de croissance d'Achatinaachatina(Linné, 1758) en élevage hors-sol. Afrique Science 09 (2): 142 - 153

Binet D., 1983. Phytoplancton et production primaire des régimes côtiers à upwelling saisonniers dans le golfe de Guinée. Océanographie Tropicale, 18 (2): 231-335.

China B., De Schaetzen M.-A., Daube G. 2003. Les mollusques bivalves, des aliments dangereux ? Annales de Médecine Vétérinaire, 2003, 147, 413422.

Costello M. J., 1990. Predator feeding strategy and prey importance: A new graphical analysis. Journal of Fish Biology, 36 : 261-263.

Dabouineau L. \& Ponsero A., 2004. Synthèse sur la biologie des coques Cerastodermaedule. Réserve Naturelle Baie de St-Brieuc, ffhal00340837v1f.https://hal.archivesouvertes.fr/file/index/docid/340837/fil ename/biologie_coques.pdf. $16 \mathrm{p}$.

Derbali A., 2011. Biologie, abondance et cartographie de deux espèces De Bivalves : l'huitre perliere pinctada radiata et la coque Glauque cerastoderma glaucum dans le golfe de gabes Thèse de Doctorat de l'université de sfax Tunisie $194 \mathrm{p}$.

Doumenc D., 1993. Gill cell culture of the butter fish clam Ruditapesdecussates. Journal of marine Biotechnology, 1:79-89.

Forcellini, M., Mathieu, C., et Merigoux, S., Atlas des Macroinvertébrés des eaux douces de l'île de la Réunion, 2011.

Gray A. E., Mulligan T. J. \& Hannah R. W.,
1997. Food habits, occurrence and population structure of the bat ray, Myliobatis californica, in Humboldt Bay. California. Environnemental Biology of Fiches Journal, 49 : 227238.

Helm M. M., Bourne N. \& Lovatelli A., 2006. Ecloserie de Bivalves. Un manuel pratique. FAO Document technique sur les pêches. No. 471. Rome. 2006. $184 \mathrm{p}$.

Hennebelle J. M., 1975. La coque. Thèse doctorat, Université de médecine de Créteil, $100 \mathrm{p}$.

Herbland A. \& Le Loeuff P., 1993. Les sels nutritifs au large de la Côte d'Ivoire :In : Environnement et ressources aquatiques de Côte d'Ivoire, (Le Loeuff, P., Marchal, E. et Amon Kothias, J.B., reds.) Tome I : Le milieu marin. ORSTOM, Paris, 123-148.

His E. \& Cantin C., 1995. Biologie et physiologie des coquillages. Ifremer, R.INT DEL/Arcachon, France, 110 p.

Hyslop E. J., 1980. Stomach contents analysis, a review of methods and their application. Journal of fish biology, 17 : 411-429.

Komàrek J. \&Anagnostidis K., 1998.Cyanoprokaryota - 1. Teil: Oscillatoriales. In :Ettlh., Gärtner. G., Heying. H. \&Mollenhawer. D. (Eds.): Süsswasserflora von Mitteleuropa 19/1, Gustav Fisher, Jena/ Stuttgart /Lübeck. 548 p.

Lauzanne L., 1975. Régime alimentaire d'Hydrocyonforskalii (Pisces.

Characidae) dans le lac Tchad et ses tributaires. Série Hydrobiologie, 9: 105-121.

Lubet P., 1973. Exposé synoptique des données biologiques sur la moule, Mytilusgalloprovincialis - Synopsis FAO sur les pêches, $\mathrm{N}^{\circ} 88,122 \mathrm{p}$.

Paugy D. \& Lévêque C., 1999. Régimes alimentaires et réseaux trophiques. In : 
les poissons des eaux continentales africaines : Diversité, écologie et utilisation par l'homme. (Levêque, C., et Paugy, D., Eds.) Editions IRD, Paris. 167-190.

Paulmier Gerard (1992). Catalogue illustré des microphytes planctoniques et benthiques des côtes normandes. DRV-92.007-RH/Le Robert. IFREMER, France. $107 \mathrm{p}$. https://archimer.ifremer.fr/doc/00119/2 3060/

Pernet F., Malet N., Pastoureaud A., Vaquer A., Quéré C. \&Dubroca L., 2012. Les Diatomées marines à l'origine de la croissance des Bivalves dans une lagune méditerranéenne, Journal of Sea Research, $68: 20-32$.

Pourriot R., 1980. Les rotifères. In Flore et faune aquatiques de l'Afrique SahéloSoudanienne ; Durant, J. R. et Levêque, C., ORSTOM, Paris : 219244.

Pourriot R., Capblancp, J. Champ, P. \& Meyer, J. A., 1982. Ecologie du plancton des eaux continentales. Vol. 16. Masson, Paris, 198 p.

Reneerkens J., Piersma T. \& Spaans B., 2005.De Waddenzee alskruispunt van vogeltrekwegen. Den Burg, KoninklijkNederlandsInstituutvoorOnd erzoek der Zee (NIOZ). NIOZ-rapport : 4, 1-125.

Reyssac J., 1993. Phytoplancton et production primaire dans les eaux marines ivoiriennes. In Environnement et ressources aquatiques de Côte d'Ivoire. Tome I : Le milieu marin (Le Loeuff, P., Marchal, E. et Amon Kothias, J. B. eds.). ORSTOM, Paris, 151-166.

Sarà G., 2007. Sedimentary and particulate organic matter: mixed sources for cockle Cerastoderma glaucum in a shallow pond, western Mediterranean. Aquatic Living Resources, 20: 271277.

Schoener T. W., 1970. Non-synchronous spatial of lizards in patchy habitats. Ecology, $51:$ 408-418.

\section{How to cite this article:}

Kouato Fulgence, Kouakou Fokouo Kessia Irène, Agnissan Aka Jean-Paul and Otchoumou Atcho. 2021. Food and Feeding Habits of the Bivalve Cardium costatum (Linné, 1758) in the Exclusive Economic Zone of Côte d'Ivoire. Int.J.Curr.Microbiol.App.Sci. 10(09): 391-401. doi: https://doi.org/10.20546/ijcmas.2021.1009.045 